\title{
TRANSFORMATION OF STRATEGIC TYPES: AN EXAMINATION OF THE INTERNAL ANTECEDENTS TO ORganizational Change
}

\author{
Charles E. Bamford \\ Texas Christian University \\ Fort Worth, TX \\ Patrick R. Rogers \\ North Carolina A\&T State University \\ Greensboro, NC \\ Alex Miller \\ University of Tennessee \\ Knoxville, TN
}

\begin{abstract}
A change in the strategic direction of an organization is usually regarded as a deliberate effort to impact firm performance. Yet empirical examinations of the drivers of organizational transformations have been inconclusive. In this study of banks, results indicate that financial performance is inversely related to a transformation of strategic type while changes in the dominant coalition are significant predictors of subsequent change in the firm's strategic type. It appears that a firm's ability to change its strategic focus is highly dependent upon it changing the membership of its Board of Directors, CEO, and its top management team.
\end{abstract}

\section{"To dispose a soul to action we must upset its equilibrium" \\ Eric Hofer, 1964}

Researchers have been able to identify a variety of strategic types and to document some aspects of the shift from one type of strategy to another (Zajac \& Shortell, 1989). While such transformations may not be uncommon, a change from one type of strategy to another is surely one of the most significant events in the life of an organization (Chakravarthy, 1982; Ginsberg, 1988; Miller \& Friesen, 1980). The number of risky procedural and organizational adjustments necessitated by such a transformation makes the very process firm-threatening (Cool \& Schendel, 1988; Tushman \& Romanelli, 1986). Yet, theory suggests that despite the risks involved, a change in the type of strategy an organization pursues often is an important means of avoiding the even greater disruptions incurred by an organization that is no longer aligned with its environment (Andrews, 1971; Miles \& Snow, 1978). 
Given the risks involved in transforming an organization from one strategic type to another, the potentially greater risks of not making such a transformation if it is needed to maintain the firm's alignment with its environment, and the documented fact that transformation of type are not uncommon, it is clear that we need to understand how and why such transformations take place (Chakravarthy, 1982; Dutton \& Duncan, 1987; Ginsberg, 1988; Miller \& Friesen, 1980; Zahra \& Pearce, 1990; Zajac \& Shortell, 1989). Such research would ideally address two deficiencies in the extant literature.

First, few researchers have used a longitudinal framework to examine the process by which organizations change from one type of strategy to another (Ginsberg, 1988; Zahra \& Pearce, 1990). Cross sectional designs, while helpful in understanding the current state of the adaptive process, or even the alignment of internal structures with a given strategy, are of little aid in understanding the antecedents to a strategic change which embody a temporal dimension (Meyer, Tsui \& Hinings, 1993).

Second, within the relevant literature there has been an overwhelming tendency to focus on environmental forces outside the firm as the primary stimulus to change (Chakravarthy, 1982; Ginsberg, 1988; Goodstein \& Boeker, 1991; Miller \& Friesen, 1980). Much of this research has identified turbulent environments (Jennings \& Seaman, 1994; Virany, Tushman \& Romanelli, 1992) or even specific environmental discontinuities (Meyer, 1982; Tushman \& Anderson, 1986) as the triggering device that pushes the organization toward a change in the strategy of the whole organization. While this stream of research has yielded some interesting findings, it is conceptually limiting as one of the fundamental strategic management prescripts depict strategic change as a deliberate managerial effort to align the company with its environment (Andrews, 1971; Child, 1972; Jennings \& Seaman, 1994).

Firm specific, internally-focused antecedents to changes in strategy type have not been examined with the same effort when compared to the examination of environmental antecedents, but, theory, research results, and anecdotal evidence can be pieced together to suggest important organizational antecedents to a transformation of type. As the following section will explain, these include changes in financial performance (Dutton \& Duncan, 1987; Ginsberg, 1988; Tushman \& Romanelli, 1985), and changes in the dominant coalition (Chandler, 1962; Ginsberg, 1988; Keck \& Tushman, 1993; Tushman \& Romanelli, 1985; Wiersema \& Bantel, 1992). This study reflects an effort to improve our understanding of strategic type changes with a direct examination of these antecedents through the longitudinal analysis of a single industry.

\section{Antecedents to a Change in Strategic Type}

Much of the research into changes in strategic types has utilized a typology such as that presented by Miles and Snow's (1978) adaptive typology (James \& 
Hatten, 1994; Jennings \& Seaman, 1994; Zajac \& Shortell, 1989). The four types (Prospector, Defender, Analyzer and Reactor) represent not only a strategic posture, but a complete organizational configuration that is consistent with the firm's strategy. The Miles \& Snow strategic types allow the researcher to directly access the realized strategy of the firm at various points in time (Zajac \& Shortell, 1989).

A change in strategic type is a fundamental process of reorganizing the structure, processes, procedures and power within an organization (Tushman \& Romanelli, 1985). Miles and Snow explain that a transformation from one strategic 'type' to another is both difficult and rare. In general, most executives will express satisfaction with their current strategy. However, they suggest that a complete change in the processes of the organization may be required if a strategic change is initiated by a change in the dominant coalition, a change in the environment or by unintended outcomes of the current strategy. While never directly tested, an examination of the extant literature also suggests several primary organizational elements that may be important internal antecedents to strategic change.

\section{Changes in the Dominant Coalition}

Strategic decisions are the function of the apex of the organization, sometimes referred to as the dominant coalition (Cyert \& March, 1963). This dominant coalition is generally thought to be a function of the interactions among three groups: 1) the CEO or president; 2) the members of the board of directors and 3) the members of the top management team (Finkelstein \& Hambrick, 1990). A substantial body of research suggests that changes in the makeup of the dominant coalition may be crucial for overcoming organizational inertia and the effects of strategic myopia (Chandler, 1962; Finkelstein \& Hambrick, 1990; Goodstein \& Boeker, 1991; Tushman \& Romanelli, 1985; Virany, Tushman \& Romanelli, 1992; Wiersema \& Bantel, 1992). The dominant coalition's perception of the environment, the alignment of corporate strategy with the environment, as well as the assessment of their company's strengths and weaknesses, appear to be critical factors in the decision to change strategies (Dutton \& Duncan, 1987; Tushman \& Romanelli, 1985). In this light, it is important to note that Miles and Snow (1978) suggested that the management of an organization would be likely to express satisfaction with their current strategy unless the dominant coalition is relatively new or the environment has changed dramatically. Both situations occurred in the banking industry during the early 1980 's. The environment changed dramatically with the authorization of limited interstate banking. Two relatively stable banks based in North Carolina (NationsBank [recently merged with Bank America] and First Union) radically changed their management team and subsequently their approach to banking. Changes in the management team disrupt the status quo and general inertia of the organization. As more members of this dominant coalition are replaced, we would expect the likelihood of a dramatic shift in the organization to take place. Given this discussion, we hypothesize the following: 
Hypothesis 1: Change in the dominant coalition will be positively related to subsequent change in the strategic type of the firm.

\section{Changes in Financial Performance}

Financial performance variables are the primary indicators with which the dominant coalition measures the effectiveness of their current strategy (Ginsberg, 1988). Two of the most important measures of financial performance are profitability and growth (Capon, Farley \& Hoenig, 1990). These variables are used to monitor the health of the organization as well as to evaluate the dominant coalition (Hannan \& Freeman, 1984). Interestingly enough, the association between organizational performance and changes in the strategic type of the firm has yet to be established (Ginsberg, 1988).

Tushman and Romanelli suggested that a decline in performance would trigger "a shift in perceptions of key strategic contingencies" (1985, pp. 201) and Goodstein and Boeker (1991) found moderate support for the contention that poor prior performance might have an impact on changes in the strategy of the firm. However, Wiersema and Bantel (1992) found a positive relationship between firm performance and a change in the scope of the firm (defined as diversification change), while Romanelli and Tushman (1994) did not find a significant relationship between poor firm performance and revolutionary organizational transformations. This confusing set of findings leaves current researchers and practitioners with little empirical guidance.

In spite of this, it is conceptually difficult to hypothesize that a change of strategic types would be undertaken during periods of high performance. High performing firms would, by explication, seem to have a good fit with their environment and therefore have little incentive to initiate a dramatic change within the firm (Ginsberg, 1988). Consider Walt Disney Company, a firm that has enjoyed a track record of success rarely achieved by corporations. Profitability and growth have been on a ten-year trend of improvement resulting from an aggressive, consistent strategy of total family entertainment. No change in Disney's strategic type is anticipated by their management nor desired by the stock market (Huey, 1995). Miles and Snow (1978) further suggested that unintended outcomes of a firms' strategy may independently push the firm toward a change in its strategic type. In keeping with this more intuitive and conceptually supportable approach, we hypothesize the following:

Hypothesis 2a: The profitability of a firm is inversely related to a subsequent change in the strategic type of the firm.

Hypothesis $2 \mathrm{~b}$ : The growth of a firm is inversely related to a subsequent change in the strategic type of the firm. 


\section{Methodology}

\section{Sample and Data}

A study of organizational antecedents to changes in strategic types requires that we attempt to control for environmental effects by selecting a single industry as opposed to a large multi-industry approach (Spender, 1983). We chose to analyze the banking industry for the period 1989-1993. This period (while a growth period in banking) was characterized by its absence of significant discontinuities as defined by prior studies (Kelly \& Amburgey, 1991; Romanelli \& Tushman, 1994; Tushman \& Romanelli, 1985).

Data was collected from both primary and secondary sources. Since transformations of type are expected to be relatively rare, a large sample was chosen. Primary data was collected during the fall of 1993 in the form of a survey of 924 U.S. banks randomly selected from all fifty states as listed in the 1990 Rand McNally Bank Directory. Bank size was controlled by selecting banks using an existing bank classification scheme. For this research, we chose banks in the medium-asset class ( $\$ 50$ million to $\$ 1$ billion in assets) which are more likely to be engaged in the singular business of consumer banking (Roussakis, 1984). The large-asset class banks tend to be diversified (e.g. brokerage operations, insurance subsidiaries and credit card centers) giving rise to multiple business level strategies and making it more difficult to accurately determine the appropriate segmentation of performance and the potential for the use of separate business unit strategies. The medium asset class banking organizations allowed us to evaluate the realized strategies of the entire organization (Shortell \& Zajac, 1990). Survey responses were received from 255 bank CEOs or $27.6 \%$ of those initially surveyed. The respondents classified themselves utilizing the Miles and Snow (1978) typology as: Prospectors - 71 (27.8\%), Defenders - 86 (33.7\%), Analyzers - $80(31.4 \%)$ and Reactors - $18(7.1 \%)$. Each CEO was asked to classify their firm's current strategy as well as their strategy during the previous one to three year period (Zajac \& Shortell, 1989) based on written descriptions of Miles and Snow strategy types developed by McDaniel and Kolari (1987) specifically for the banking industry (Appendix A). Due to missing archival data, the sample was reduced to 227 of which 65 banks or $28.6 \%$ reported a change in their strategic type between their current strategy and the one pursued during the previous one to three years.

The data was analyzed for potential response bias. No differences were found with either regional disparities or size between firms that had changed their type and those that did not. Furthermore, an analysis of response bias by size or performance between respondent and non-respondent firms found no significant differences.

\section{Variables and Measures}

Transformation of Types. In keeping with our research objectives, the Miles and Snow (1978) typology allowed us to directly assess the change in type from the perspective of the decision-maker. Zajac and Shortell (1989) used this typol- 
ogy to conceptualize firm strategy in a similar way. In their case, CEOs were asked to categorize the strategy type that best described their firm (hospitals) currently as well as during the prior two years. This method of evaluating realized strategies has been shown to be both reliable and valid (Shortell \& Zajac, 1990). By comparing current strategy to prior strategy, they were able to develop a change of strategic type variable.

Change in Strategic Type. This was coded as a binary categorical dependent variable (1-Change, 0 - No Change). The limited number of banks that reported a change in strategic type prevented an analysis of all the individual types of change, therefore, a binary variable seemed the most appropriate. However, changes from any one to another of the Miles and Snow types represents a change in the processes, direction and internal mechanisms of the organization. The questionnaire was completed by CEOs using descriptive paragraphs of each of the four Miles and Snow strategic types which were tailored for the banking industry (McDaniel \& Kolari, 1987). Furthermore, the use of the Miles and Snow typology in this manner has been shown to have high measurement validity (James \& Hatten, 1994; Shortell \& Zajac, 1990). CEO's were used as the key individual for assessing the firm's overall strategy (Shortell \& Zajac, 1990; Snow \& Hrebiniak, 1980).

To assess the reliability of the CEOs classification of strategic type, state bank supervisors (or a recommended and qualified substitute within the supervisory office) were selected as an appropriate expert group to validate the strategy type chosen by CEOs. Forty-one state banks supervisory offices agreed to participate. These experts were asked to classify the strategic type of each identified bank in their state. The alpha coefficient between Expert and CEO agreement was .84 adding to our confidence that we were tapping into realized strategy.

Change in the dominant coalition is comprised of changes in three groups within the firm. They are: 1) the CEO/President; 2) the members of the board of directors, and 3) the members of the top management team. Archival measures of the changes in the membership of the dominant coalition as well as prior firm performance were gathered from the Polk's Bank Directory (North America)-Spring Edition for the period 1989-1993.

Change in CEO. CEO change was coded as a binary variable with 1 representing a change in $C E O$ and a 0 representing no change in $C E O$ (Keck \& Tushman, 1993). None of the banks examined had more than one change in CEO during the period examined.

Change in BOD. Board of Directors change was coded on an interval scale with each change in the BOD being coded as a 1 . All changes were summed for a total change in the Board. We then calculated a proportional change in each board in order to adjust for various board sizes (Goodstein \& Boeker, 1991). In order to minimize potential confounding effects in the data, we did not count a CEO change or top management team change as a BOD change.

Change in TMT. It is widely understood that banks in general and small banks in particular reward employees with officer titles. These titles are often referred 
to as "dry promotions" as they include no additional remuneration. Furthermore, they are often awarded for reasons other than holding a significant strategic position within the firm (e.g. long tenure, community visibility). This makes archival identification of the true members of the TMT difficult. In keeping with prior literature, Top Management Team changes were defined as those members of the management team that held the title of Senior Vice President and above. The coding system mirrored that used for BOD changes.

Change in Dominant Coalition. Given the multi-faceted nature of the dominant coalition (Ginsberg, 1988), we utilized a single measure (varimax-rotated factor analysis) for the dominant coalition which was composed of the change in CEO, change in BOD and change in TMT.

Financial Performance. We obtained four archival performance measures to analyze the separate effects of firm profitability and firm growth. They were: 1) Return on Assets (ROA); 2) Return on Equity (ROE); 3) Average annual loan growth (LG) and 4) Average annual deposit growth (DG). These were collected from the Polk's Bank Directory (North America) - Spring Edition for the period 1993-1995 (Wiersema \& Bantel, 1992; Zajac \& Shortell, 1989). These measures are the predominant measures of financial performance in the banking industry and are reported in a standard, well regulated manner (Garcia, 1985; Roussakis, 1984))

\section{Results}

Table 1 presents the means, standard deviations, and correlations for the variables used in this study.

Table 2 presents the rotated factor loadings for each of our variables. Three factors are apparent: 1) Dominant Coalition; 2) Profitability and 3) Growth. Table 3 presents the results of the three separate logistic regression models. Hypothesis 1 predicts that change in the strategic type of a firm will be preceded by changes in the dominant coalition. Model 1 utilizes our dominant coalition factor score and yields a positive and significant beta $(p<.001)$. Changes in the dominant coalition are strongly related to a subsequent transformation of type. Thus, hypothesis 1 appears to be strongly supported.

Hypotheses $2 \mathrm{a}$ and $2 \mathrm{~b}$ suggested that firm profitability and growth would be inversely related to a subsequent change in strategic type. These hypotheses are partially supported. Using the factor loadings, model 2 of our logistic regression found a negative and somewhat significant $(p<.10)$ beta for firm profitability, Model 3 included firm growth, which had a negative beta, but was not statistically significant. The negative betas suggest an inverse relationship between firm profitability and growth with a subsequent transformation of type and as this was hypothesized, we conclude that hypothesis $2 \mathrm{a}$ is supported and $2 b$ is not supported. 
Table 1

Summary Statistics and Correlations ${ }^{x}$

\begin{tabular}{|c|c|c|c|c|c|c|c|c|c|}
\hline Variable & Mean & s.d. & 1 & 2 & 3 & 4 & 5 & 6 & 7 \\
\hline 1. Change in Strategic Type & 0.2915 & 0.4555 & & & & & & & \\
\hline 2. CEO change & 0.2063 & 0.4055 & $.24^{* * *}$ & & & & & & \\
\hline 3. BOD change & 0.2679 & 0.3583 & $.21 * * *$ & $.41^{* * *}$ & & & & & \\
\hline 4. TMT change & 0.3172 & 0.5377 & $.21 * * *$ & $.76 * * *$ & $.49 * * *$ & & & & \\
\hline 5. Average $\mathrm{ROA}$ & 0.0057 & 0.0031 & $-.20 * * *$ & $-.15 * *$ & $-.14 * *$ & -.10 & & & \\
\hline 6. Average ROE & 0.0635 & 0.0407 & $-.12^{*}$ & -.05 & $-.13^{*}$ & -.04 & $.71^{* * * *}$ & & \\
\hline 7. Loan Growth & 0.0523 & 0.1261 & -.06 & -.08 & .02 & .01 & $.21^{* * *}$ & $.28 * * *$ & \\
\hline 8. Deposit Growth & 0.0725 & 0.1175 & -.07 & $-.17 * *$ & $-.13^{*}$ & $-.14 * *$ & $.18^{* *}$ & $.21 * * *$ & $.51 * * *$ \\
\hline
\end{tabular}

${ }^{2} \mathrm{~N}=227$

${ }^{*} \mathrm{p}<.05$

${ }^{* *} \mathrm{p}<.01$

$* * * \mathrm{p}<.001$ 
Table 2

Factor Analysis of Antecedents"

\begin{tabular}{lccc}
\hline Variable & Dominant Coalition & Proftability & Growth \\
\hline TMT Change & 0.9121 & -0.0241 & 0.0102 \\
CEO change & $\mathbf{0 . 8 5 4 6}$ & 0.0000 & -0.0975 \\
BOD change & $\mathbf{0 . 7 5 5 4}$ & -0.1108 & -0.0998 \\
Average ROE & -0.0408 & $\mathbf{0 . 9 0 7 2}$ & 0.1437 \\
Average ROA & -0.0796 & $\mathbf{0 . 9 0 6 7}$ & 0.0280 \\
Deposit Growth & -0.1789 & -0.0869 & $\mathbf{0 . 8 4 5 2}$ \\
Loan Growth & 0.0305 & 0.3150 & $\mathbf{0 . 7 6 1 8}$ \\
& & & \\
Factor eigenvalues & 2.3981 & 1.7495 & 1.1268 \\
Petcent Explained & $34.30 \%$ & $25.00 \%$ & $16.10 \%$ \\
\hline
\end{tabular}

- Factor Loadings are in Bold

Table 3

Results of Logistic Regression Analysis ${ }^{\mathrm{a}}$

\begin{tabular}{lccc}
\hline & Model 1 & Model 2 & Model 3 \\
\hline Dominant Coalition & $.58^{* * *}$ & $.60^{* * *}$ & $.60^{* * *}$ \\
Profitability & $(.15)$ & $(.16)$ & $(.16)$ \\
& & $-.27^{\dagger}$ & $-.27^{\dagger}$ \\
Sales Growth & & $(.15)$ & $(.15)$ \\
& & & -.03 \\
Constant & & & $(.15)$ \\
& -.94 & -.95 & -.95 \\
Model Chi-Square & $(.15)$ & $(.16)$ & $(.16)$ \\
Percent Classified & $16.02^{* * * *}$ & $19.24^{* * *}$ & $19.30^{* * *}$ \\
& $72.20 \%$ & $73.54 \%$ & $73.99 \%$ \\
Siandard errors are in parestheses. & & & \\
***P $<.001$ & & & \\
$* * * \mathrm{P}<.01$ & & & \\
$* \mathrm{P}<.05$ & & & \\
$+<.10$ & & &
\end{tabular}

\section{Discussion}

Based on the results, it is clear that it is not unusual for organizations to change from one strategic type to another. Zajac and Shortell (1989) found that over half of the organizations they studied, $55 \%$ to be more precise, accomplished such a 
transformation during the two-year time period they studied. These results may not be too surprising given that Zajac and Shortell specifically targeted turbulent environments. However, even in the relatively stable banking industry, we found that almost three out of every ten banks underwent a change of strategic type during the three-year time period we studied. While it would be enlightening to have comparable data from additional industries and environments, it seems clear that changes in strategic types are a relatively common phenomenon. Our results also provide some evidence regarding the antecedents to a transformation of strategic types. The strongest results relate to changes in the dominant coalition. This variable was a composite of changes in the top management team, changes in the CEO position, and changes among members of the board of directors. In our analysis, changes in the dominant coalition were clearly and consistently linked to transformation of types. For example, among firms in our sample that did not undergo a transformation of type, only $14 \%$ had experienced a change in their CEO. This is in sharp contrast to the subsample of firms that did undergo a transformation of type, where $35 \%$ of the firms had experienced a change in their CEO. To understand the predictive power of Dominant Coalition Change in predicting a transformation of strategic type, compare Model 1 from Table 3 to any of the other models in that table. Knowing whether or not there has been a change in the dominant coalition is sufficient to allow us to correctly classify $72 \%$ of all the firms in our sample. Adding all the terms in our most complex model only improves our classification rate by approximately two percentage points.

Having said this, we need to point out that profitability was also a statistically significant predictor of transformation of type. The size of the effect was generally smaller, and it added little to our classification ability, but the finding supports the original proposition of Tushman and Romanelli (1985), who suggested that poor prior performance might be associated with an organizational reorientation. Interestingly enough, their most recent research, which studied the effects around environmental discontinuities, found an insignificant connection between poor prior performance and a 'revolutionary transformation' within the firm (Romanelli \& Tushman, 1994: 1158). Our study did not have the fine grained detail of the Romanelli and Tushman study and as such our knowledge of the organizational impact on the complete adaptive cycle of a change in strategic direction is limited.

The weight of these various observations seems to suggest that there may be fundamental differences in both the factor and response mechanisms between relatively stable and unstable environments when analyzing transformations of type. In environments not identified with an environmental discontinuity, detection of needed change in type may be more focused upon factors within the firm. Examining profitability, replacing members of the dominant coalition and perhaps as Goodstein and Boeker (1991) suggest, changes in organization structural variables are attempted as a precursor to a change in strategy. However, when the environment has changed dramati- 
cally, the need to change is more obvious and the change is initiated by removing various perceived impediments to the implementation of the new strategy (Keck \& Tushman, 1993).

While change in the dominant coalition was an important place to start looking for antecedents of strategic change, it is not difficult to identify other possibilities. For example, changes in organization structure, changes in reward systems, and changes in funding patterns would all be plausible candidates for study. However, as one moves beyond the most distinct antecedents and into other possibilities, it becomes less clear what constitutes an antecedent and what constitutes part of an implementation effort facilitating the transformation of type after a decision has already been made to bring about such a change. Furthermore, this study was focused on a single, regulated industry. While we believe that there are significant advantages to be gained from such focused research, we do not wish to suggest that this pattern exists outside of the banking industry. That is the subject of future research efforts.

Another interesting set of questions raised by the present research deals with the generalizability of the results. The questions here deal with generalizability across industries, however, we find that a more interesting question concerns generalizability across different combinations of transformations of type. For example, are the antecedents relevant to a transformation from Prospector to Defender the same as those relevant to a transformation from Defender to Prospector? How about a change from Reactor to Analyzer or vice versa. Using the relatively simple four-part Miles and Snow typology, there are 12 possible combinations of transformations. A lack of data prohibited our controlling for the specific form of transformation, which has the benefit of a set of results more likely to be generalizable across the twelve different possibilities. However, what we gain in generalizability, we lose in accuracy, and it would be useful to see how our results would differ from one form of transformation to another.

The results from this study offer some interesting implications for managers and organizations. It is not unusual for top executives to implore their organizations to undertake major changes in strategic orientation and to bemoan the resistance to change their organizations display. Our results show that one of the most important antecedents in a change of strategies is a change in the dominant coalition of the firm. This may hint at a fundamental difficulty in bringing about transformation in strategic types. How often will executive teams be willing to replace themselves in order to help bring about a needed strategic transformation? Of course, there is also a sort of converse logic that applies to the link between changes in the dominant coalition and changes in strategic types. How often do changes in the executive ranks lead to changes in strategy that would not otherwise be needed or motivated? There is a commonly observed phenomenon in which an individual offered a seat will not simply sit down, but instead will reposition the chair before being seated. There was nothing wrong with the chair's original position and there is nothing inherently better about the chair's new position. Could execu- 
tives be making similarly unnecessary adjustments when they are offered new "seats"? Given the costs and risks associated with major strategic changes, this is a potentially important question.

Research into this aspect of firm alignment offers a unique perspective of dominant coalition actions. Pressures to perform and an increasing trend to hold members of the dominant coalition responsible for firm outcomes (Pettigrew, 1992) suggest that these events provide a needed window into the strategic decision making aspect of organizations and offer ample incentive for continued research into the antecedents of the transformation of strategic types.

\section{References}

Andrews, K. R. (1971). The concept of corporate strategy. Irwin, Homewood, IL.

Capon, N., Farley, J. U. \& Hoenig, S. (1990). Determinants of financial performance: A meta-analysis. Management Science, 36 (10), 1143-1159.

Chakravarthy, B. S. (1982). Adaptation: A promising metaphor for strategic management. Academy of Management Review. 7 (1), 35-44.

Chandler, Jr., A. D. (1962). Strategy and structure: Chapters in the history of the American industrial enterprise. The MIT Press, Cambridge, MA.

Child, J. (1972). Organization structure, environment and performance: The role of strategic choice. Sociology, 6, 1-22.

Cool, K. \& Schendel, D. E. (1988). Performance differences among strategic group members. Strategic Management Journal. 9, 207-223.

Cyert, R., \& March, J. (1963). A behavioral theory of the firm. Prentice-Hall, Englewood Cliffs, NJ.

Dutton, J. E. \& Duncan, R. B. (1987). The creation of momentum for change through the process of strategic change diagnosis. Strategic Management Journal. 8, 279-295.

Garcia, F. L. (1985). How to analyze a bank statement. (7th ed). Bankers Publishing Co., Boston, MA.

Ginsberg, A. (1988), Measuring and modeling changes in strategy: Theoretical foundations and empirical directions. Strategic Management Journal. 9, 559-575.

Goodstein, J. \& Boeker, W. (1991). Turbulence at the top: A new perspective on governance structure changes and strategic change. Academy of Management Journal, 34 (2), 306-330. 
Finkelstein, S. \& Hambrick, D. C. (1990). Top-management-team tenure and organizational outcomes: The moderating role of managerial discretion. Administrative Science Quarterly, 35, 484-503.

Hannan, M. T. \& Freeman, J. (1984). Structural inertia and organizational change. American Sociological Review, 49, 149-164.

Hofer, E. (1964). The ordeal of change. Harper \& Row Publishers, New York.

Huey, J. (1995). Eisner explains everything. Fortune 131 (7), 44-68.

James, W. L. \& Hatten, K. J. (1994). Evaluating the performance effects of Miles' and Snow's strategic archetypes in banking, 1983 to 1987: Big or small? Journal of Business Research. 31, 145-154.

Jennings, D. F. \& Seaman, S. L. (1994). High and low levels of organizational adaptation: An empirical analysis of strategy, structure, and performance. Strategic Management Journal_ 15, 459-475.

Keck, S. L. \& Tushman, M. L. (1993). Environmental and organizational context and executive team structure. Academy of Management Journal, 36 (6), 1314-1344.

Kelly, D. \& Amburgey, T. L. (1991). Organizational inertia and momentum: A dynamic model of strategic change. Academy of Management Journal, 34 (3), 591-612.

McDaniel, S. W. \& Kolari, J. W. (1987). Marketing strategy implications of the Miles and Snow strategic typology. Journal of Marketing. 51 (4), 19-30.

Meyer, A. D. (1982). Adapting to environmental jolts. Administrative Science Quarterly, 27, 515-537.

Meyer, A. D., Tsui, A. S. \& Hinings, C. R. (1993). Configurational approaches to organizational analysis. Academy of Management Journal, 36 (6), 1175-1195.

Miles, R. E. \& Snow, C. C. (1978). Organizational strategy, structure, and process. McGrawHill, New York.

Miller, D. \& Friesen, P. H. (1980). Momentum and revolution in organizational adaptation. Academy of Management Journal, 23 (4), $591-614$.

Pettigrew, A. M. (1992). On studying managerial elites. Strategic Management Journal, $\underline{13}, 163-182$.

Romanelli, E. \& Tushman, M. L. (1994). Organizational transformations as punctuated equilibrium: An empirical test. Academy of Management Journal, 37 (5), 1141 - 1166. 
Roussakis, E. N. (1984). Commercial banking in an era of deregulation. Praeger Publishers, New York.

Shortell, S. M. \& Zajac, E. J. (1990). Perceptual and archival measures of Miles and Snow's strategic types: A comprehensive assessment of reliability and validity. Academy of Management Journal, 33 (4), 81 7-832.

Snow, C. C. \& Hrebiniak, L. G. (1980). Strategy, distinctive competence, and organizational performance. Administrative Science Quarterly, 25, 317-336.

Spender, J. C. (1983). The business policy problem and industry recipes. In R. Lamb (ed.) Advances in Strategic Management, 2, 211-229. JAI Press, Greenwich, CT.

Tushman, M. L. \& Anderson, P. (1986). Technological discontinuities and organizational environments. Administrative Science Quarterly, 31, 439-465.

Tushman, M. L. \& Romanelli, E. (1985). Organizational evolution: A metamorphosis model of convergence and reorientation. In L. L. Cummings and Barry M. Straw (eds.). Research in Organizational Behavior. 7, 171-222. JAI Press, Greenwich, CT.

Virany, B., Tushman, M. L. \& Romanelli, E. (1992). Executive succession and organization in turbulent environments: An organization learning approach. Organization Science. 3 (1), 72-91.

Wiersema, M. F. \& Bantel, K. A. (1992). Top management team demography and corporate strategic change. Academy of Management Journal, 35 (1), 91-121.

Zahra, S. A. \& Pearce, J. A. III (1990). Research evidence on the Miles-Snow typology. Journal of Management. 16 (4), 751-768.

Zajac, E. J. \& Shortell, S. M. (1989). Changing generic strategies: Likelihood, direction, and performance implications. Strategic Management Journal, 10, 413-430. 


\section{Appendix A}

WHICH ONE OF THE FOLLOWING DESCRIPTIONS MOST CLOSELY FITS YOUR BANK COMPARED TO OTHER BANKS IN THE INDUSTRY? (PLEASE CONSIDER YOUR BANK AS A WHOLE AND NOTE THAT NONE OF THE TYPES LISTED BELOW ARE INHERENTLY "GOOD" OR "BAD.")

\section{TYPE 1}

This bank attempts to locate and maintain a secure niche in a relatively stable product or service area. The bank tends to offer a more limited range of products or services than its competitors, and it tries to protect its domain by offering higher quality, superior service, lower prices, and so forth. Often this bank is not at the forefront of developments in the industry - it tends to ignore industry changes that have no direct influence on current areas of operation and concentrates instead on doing the best job possible in a limited area.

\section{TYPE 2}

This bank typically operates within a broad product-market domain that undergoes periodic redefinition. The bank values being "first in" in new product and market areas even if not all of these efforts prove to be highly profitable. The organization responds rapidly to early signals concerning areas of opportunity, and these responses often lead to a new round of competitive actions. However, this bank may not maintain market strength in all of the areas it enters.

\section{TYPE 3}

This bank attempts to maintain a stable, limited line of products or services, while at the same time moving out quickly to follow a carefully selected set of the more promising new developments in the industry. The bank is seldom "first in" with new products or services. However, by carefully monitoring the actions of major competitors in areas compatible with its stable product-market base, the bank can frequently be "second in" with more cost-efficient product or service.

\section{TYPE 4}

This bank does not appear to have a consistent product-market orientation. The bank is usually not aggressive in maintaining established products and markets as some of its competitors, nor is it willing to take as many risks as other competitors. Rather, the bank responds in those areas where it is forced to by environmental pressures. 
Charles E. Bamford received his Ph.D. in Strategic Management and Entrepreneurship from the University of Tennessee-Knoxville. During a twelve-year career prior to joining the University of Tennessee, Dr. Bamford was the head of the Business Analysis Department (Mergers \& Acquisitions, Dispositions, and Small Business Consulting) for a super-regional bank holding company. His research has been published in Strategic Management Journal, Journal of Business Venturing as well as the Frontiers of Entrepreneurship Research.

Patrick R. Rogers received his Ph.D. in Strategic Management from the University of Tennessee-Knoxville. He is an Assistant Professor of Management at North Carolina A\&T State University, Greensboro, NC. Professor Rogers research interests include strategic planning, strategic information as competitive advantage, organizational learning styles and organizational learning disabilities. His research has been published in the Strategic Management Journal.

Alex Miller is the William B. Stokely Professor of Management at the University of Tennessee-Knoxville. He earned an MBA from Amos Tuck School of Business at Dartmouth College, where he was a Tuck Scholar and a Ph.D. from the University of Washington. His research has been published in such journals as the Academy of Management Journal, Journal of Business Research, Journal of Business Venturing, Strategic Management Journal, and Journal of Management Studies. 